\title{
ERA-CLIM \\ Historical Surface and \\ Upper-Air Data for Future Reanalyses
}

by A. Stickler, S. Brönnimann, M. A. Valente, J. Bethike, A. Sterin, S. Jourdain, E. Roucaute, M. V. Vasquez, D. A. Reyes, R. Allan, and D. Dee

Newly digitized surface and upper-air data are useful to analyze climate and weather events in the first half of the twentieth century and may help to improve future reanalyses.

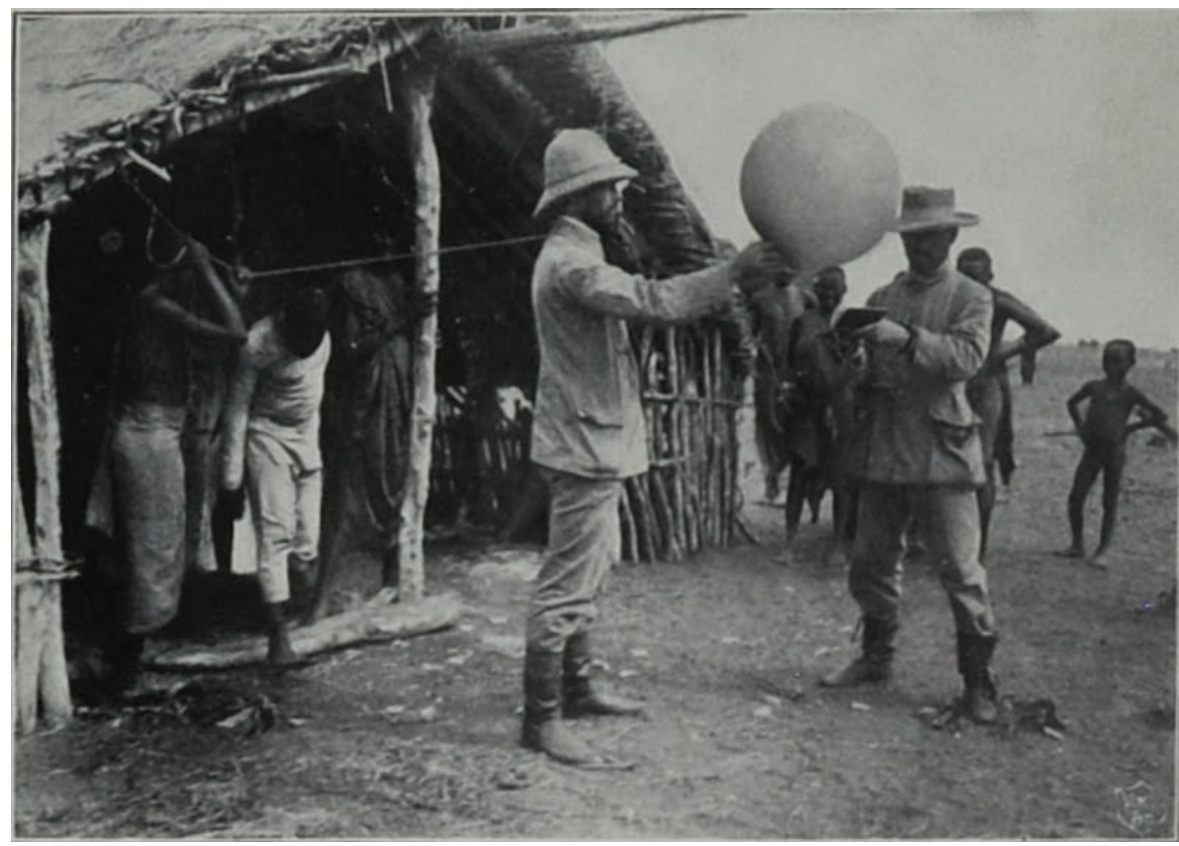

Pilot balloon ascent at the Mori Bay (Victoria Nyanza) during the German East Africa Expedition 1908 (from Berson 1910).

\footnotetext{
C urrently, several widely used reanalyses are available reaching back to at least 1958, giving physically consistent, detailed pictures of the atmospheric state in space and time: The 40-yr European Centre for Medium-Range Weather Forecasts (ECMWF) Re-Analysis (ERA-40; Uppala et al. 2005), the National Centers for Environmental Prediction (NCEP)-National Center for Atmospheric Research (NCAR) 50-yr Reanalysis (NNR; Kistler et al. 2001), the newly completed Japanese 55-year Reanalysis Project (JRA-55; Ebita et al. 2011), and the Twentieth Century Reanalysis (20CR; Compo et al. 2011). Climate Forecast System Reanalysis Lite (CFSR-lite; Saha et al. 2010) is planned to replace NNR in the near future. JRA-55, ERA-40, and NNR cover the well-observed period back to
} 
the IGY in 1957/58 and to 1948. They have used surface as well as upper-air and satellite observations. However, the relatively short period of data does not cover several prominent climate or weather events in the first half of the twentieth century. 20CR, on the other hand, has assimilated synoptic surface and sea level pressure only, using monthly sea surface temperatures and sea ice information as boundary conditions. This has allowed for an extension of the period covered by reanalyses back to 1871 . However, to date, no reanalysis has made use of the significant amount of historical upper-air data before 1948, even though this type of product is expected to profit from assimilating further historical surface as well as upper-air data.

In the framework of the European Reanalysis of Global Climate Observations (ERA-CLIM; www.era-clim.eu) project, a European Union (EU) Seventh Framework Programme for Research and Technological Development (FP7) project designed to prepare input data and assimilation systems for a new global atmospheric reanalysis of the twentieth century, significant amounts of pre-1957 upper-air and surface data have been cataloged $(>1.25$ million station days each), imaged ( $>450,000$ images), and digitized ( $>700,000$ station days each), with the aim to prepare new input datasets for upcoming reanalyses. The data rescue activities constituted one important work package of the project, besides the preparation of satellite, boundary condition, and forcing data; the integration of the observational data into the ECMWF Observation Feedback Archive (OFA);

AFFILIATIONS: STICKLER AND BRÖNNIMANN-Oeschger Centre for Climate Change Research, and Institute of Geography, University of Bern, Bern, Switzerland; VALente AND BetHKE-Fundação da Faculdade de Ciências, Instituto Dom Luiz, Universidade de Lisboa, Lisbon, Portugal; SteRIN-Russian Research Institute for Hydrometeorological Information, World Data Center, Obninsk, Russia; Jourdain and Roucaute-Météo-France, Toulouse, France; VAsQuez AND ReYES-Universidad del Pacífico, Santiago, Chile; ALLAN-ACRE, Met Office Hadley Centre, Exeter, United Kingdom; DeE-European Centre for Medium-Range Weather Forecasts, Reading, United Kingdom CORRESPONDING AUTHOR: Alexander Stickler, Klimatologie, Geographisches Institut, Universität Bern, Hallerstrasse I2, $\mathrm{CH}-30 \mathrm{I} 2$ Bern, Switzerland

E-mail: alexander.stickler@giub.unibe.ch

The abstract for this article can be found in this issue, following the table of contents.

DOI:10.1175/BAMS-D-13-00147.1

In final form 17 January 2014

(C)2014 American Meteorological Society and the quantification and reduction of errors and uncertainties in the observational data. The inventoried and digitized data cover large parts of the globe, focusing on so far less well-covered regions such as the tropics, the polar regions, and the oceans and on very early twentieth-century upper-air data from Europe and the United States. The total number of digitized/inventoried records produced in ERACLIM, in the form of time series of meteorological data at fixed stations or from moving observational platforms, is $80 / 214$ for surface stations, $735 / 1,783$ for upper-air stations, and 61/101 for moving upper-air platforms (i.e., data from ships, etc.).

A rough estimate of the relative contribution of ERA-CLIM to the total historical upper-air data record available in digital form can be obtained from Fig. 1, which will be discussed in more detail in the section on data distribution over time. In this figure, the number of Integrated Global Radiosonde Archive (IGRA) radiosonde records (Durre et al. 2006) after 1957 corresponds by and large to the number of upper-air records assimilated into ERA-40 (see Fig. 1 of Ramella-Pralungo et al. 2014). Summing up the area between the curves and using a constant number of 877 records in IGRA from 1971 onward gives an additional contribution of ERA-CLIM to the number of assimilated upper-air records $\times$ months in ERA-40 ( 415,000) of 15.9\%. Taking both ERA-40 and the Comprehensive Historical Upper-Air Network (CHUAN; Stickler et al. 2010), which already compiled large amounts of historical (i.e., pre-1957) upper-air data, together, the additional contribution of ERA-CLIM is still considerable (8.6\%). Note that, on one hand, these numbers tend to overestimate the volume of historical data, because the earlier series have generally fewer observations per day and reach lower altitudes above sea level than the more recent ones. On the other hand, the historical observations are especially valuable farther back in time, as the total number of assimilated observations in the reanalyses decreases.

A very important aspect of the project itself was the international collaboration reaching beyond the so-called European research area (http://ec.europa .eu/research/era/index_en.htm), which comprises a system of scientific research programs integrating the scientific resources of the European Union since the year 2000. Besides several institutions from countries within the European Research Area-namely, the University of Bern (UBERN; Switzerland) and the Fundação da Faculdade de Ciências da Universidade de Lisboa, together with the Dom Luiz Institute of the University of Lisbon (FFCUL; Portugal) 
and Météo-France (METFR) in Toulouse, France-two institutions from outside the European Research Area contributed to the data rescue activities of ERA-CLIM: the Russian Research Institute for Hydrometeorological Information (RIHMI) in Obninsk, Russia, and the Universidad del Pacífico (UPAC) in Santiago, Chile. As a result, ERACLIM had access to archives that were previously inaccessible to the international scientific community. Furthermore, the collaboration allowed for an intense exchange and knowledge transfer between the partner institutions with respect to data rescue techniques such as imaging, job handling (for which a web interface was developed), and experiences with optical character recognition software and quality check (QC) tests. Finally, a large, albeit still incomplete, catalog of available historical data sources was developed and made available in the form of a web-based metadatabase, which can serve as a starting point for further data rescue projects.

The data rescue activities of ERA-CLIM were organized in close arrangement with the broader Atmospheric Circulation Reconstructions over the Earth initiative (ACRE; www.met-acre.org; Allan et al. 2011) and, in the case of surface pressure and temperature data, in cooperation with the International Surface Pressure Databank (ISPD; http:// reanalyses.org/observations/international-surface -pressure-databank; Compo et al. 2011) and the International Surface Temperature Initiative (www surfacetemperatures.org; Thorne et al. 2011). The new ERA-CLIM data will be made available online (via www.era-clim.eu). The upper-air data (Stickler et al. 2014) will be included in the CHUAN collection and are also available online (at http://doi.pangaea .de/I0.I594/PANGAEA.82I222). The full station record documentation including station name, location/elevation, time coverage, measurement platform, estimated number of station days, and data source are provided online in the metadatabase (see www .oeschger-data.unibe.ch/metads). More detailed information on the cataloging and digitization of the surface and upper-air data, on the quality checks applied, and on the largest upper-air sources can be found in Morozova and Valente (2012) and Stickler et al. (2014).

\section{THE ERA-CLIM SURFACE AND UPPER-}

AIR DATA. Data sources. Potential data sources were identified in different ways. A first part of the sources was inventoried inside the archives of the institutions involved in the project (first institution in each group of the following) or in other national archives that these had access (other institutions listed): FFCUL and Portuguese national weather service Instituto Português do Mar e da Atmosfera; RIHMI; METFR and French National Archives in Fontainebleau; UPAC, Dirección Meteorológica de Chile, Naval and Maritime Museum in Valparaíso, and Chilean Navy; and Met Office (UKMO) and National Meteorological Library and Archives. These sources were often weekly, monthly, or yearly reports or original observation diaries of national meteorological services. A second part of the sources, all upper-air, was identified in a large web-based literature research conducted at UBERN. For example, further meteorological reports could be obtained from or imaged directly at libraries, but also many published reports from historical measurement campaigns and expeditions and from observatories 
were collected. ${ }^{1}$ The last part consists of sources that were already available in the form of digital images from the National Oceanic and Atmospheric Administration (NOAA) Central Library Foreign Climate Date website (http://docs.lib.noaa.gov /rescue/data_rescue_home.html).

More data sources were identified, cataloged, and imaged than could be digitized within the budget and time restrictions determined by the project plan. These additional sources, broken down to the single records, are also contained in the complete project station inventory (www.oeschger-data.unibe.ch /metads) to prevent duplicate efforts within the international data rescue community. Furthermore, they will be of great use for the continued data rescue efforts in the framework of the follow-up project ERA-CLIM2, begun in January 2014.

Imaging, digitization, quality checks, and reformatting. All identified sources were imaged with digital cameras at the different institutions in high resolution and have been centrally stored at UBERN. Digitization was done either by manual keying or, whenever possible, with optical character recognition (OCR) software. The latter method could be used extensively at FFCUL and RIHMI, where large sources were in very regular, tabular formats, but only for a small part of the very diverse sources at UBERN.

The QC consisted of flagging of suspicious values during the digitization process, checking these values afterward with the help of the digital images, and range checks. The qualification of values as suspicious was generally based on expertise, considering, for example, implausible or doubtful values such as $370^{\circ}$ for wind direction or $200 \mathrm{~m} \mathrm{~s}^{-1}$ for wind speed, strong outliers in vertical profiles of temperature and wind speed, deviations from monotonously increasing values of geopotential height with altitude, etc. Additional tests were performed with the surface data at FFCUL (e.g., consistency with monthly checksums) and with the upper-air data digitized at RIHMI (e.g., vertical consistency checks using the hydrostatic equation). Finally, departures from the new ERA-CLIM surface-only reanalysis (ERA-20C; Poli et al. 2013) were used for QC in case of the complete upper-air temperature values. The QC applied to the complete upper-air data is described in much more detail in Stickler et al. (2014). All digitized and quality checked records have been reformatted to ASCII files.

\footnotetext{
${ }^{1}$ For example, German East Africa expedition of 1908 (Berson 1910; Süring 2013; Brönnimann and Stickler 2013); the Swiss Greenland expedition of 1912/13 (de Quervain et al. 1920); the Norwegian North Polar expedition with the Maud in 1918-25 (Sverdrup 1933a,b); the German Atlantic expedition with the Research Vessel Meteor in 1925-27 (Kuhlbrodt and Reger 1933); the Greenland expedition of the University of Michigan of 1926-31 (Hobbs and Fergusson 1931); the German Greenland expedition of 1930/31 (Holzapfel et al. 1939); the Byrd Antarctic expeditions of 1928-30 and 1930-35 (Grimminger and Haines 1939); and the Canadian polar year expeditions of 1932/33 (Meteorological Services of Canada 1940; see also various reports of the Harvard, Lindenberg, Blue Hill, Mt. Weather, Samoa, Batavia, and Helwan astronomical/meteorological/magnetic observatories).
}

\begin{tabular}{|c|c|c|c|c|c|c|c|c|}
\hline \multirow{2}{*}{$\begin{array}{c}\begin{array}{c}\text { Measurement } \\
\text { platform }\end{array} \\
\text { Surface }\end{array}$} & \multicolumn{2}{|c|}{$\begin{array}{l}\text { Pre-1928 digitized, } \\
\text { inventoried }\end{array}$} & \multicolumn{2}{|c|}{$\begin{array}{l}\text { 1928-37 digitized, } \\
\text { inventoried }\end{array}$} & \multicolumn{2}{|c|}{$\begin{array}{l}\text { 1938-47 digitized, } \\
\text { inventoried }\end{array}$} & \multicolumn{2}{|c|}{$\begin{array}{l}\text { 1948-57 digitized, } \\
\text { inventoried }\end{array}$} \\
\hline & 568,573 & $1,041,209$ & 118,512 & 248,172 & 19,446 & 108,313 & 0 & 30,987 \\
\hline Aircraft & 9,116 & 12,759 & 14,077 & 25,756 & 1,421 & 3,322 & 0 & 0 \\
\hline Captive balloon & 6,423 & 7,076 & 485 & 652 & 0 & 0 & 0 & 0 \\
\hline Kite & 24,506 & 29,208 & 978 & 3,820 & 0 & 0 & 0 & 0 \\
\hline Pilot balloon & 64,198 & 188,826 & 175,044 & 416,538 & 156,273 & 221,958 & 172,229 & 334,567 \\
\hline Radiosonde & 0 & 0 & 1,368 & 1,614 & 13,336 & 21,168 & 79,710 & 164,047 \\
\hline $\begin{array}{l}\text { Registering } \\
\text { balloon }\end{array}$ & 13,368 & $|8,20|$ & 3,580 & 6,685 & 0 & 0 & 0 & 0 \\
\hline $\begin{array}{l}\text { Various moving } \\
\text { upper air }\end{array}$ & 2,717 & 2,866 & 2,256 & 5,763 & 0 & 0 & 328 & 328 \\
\hline $\begin{array}{l}\text { Atmospheric } \\
\text { transmission }\end{array}$ & 2,694 & 2,694 & 496 & 536 & 0 & 0 & 379 & 409 \\
\hline
\end{tabular}


Distribution of the data in space and time. As can be seen from Table 1, the largest fraction of the inventoried and digitized data with respect to station days consists of regular surface station and pilot balloon wind observations. After 1938, radiosonde observations also contribute significantly to the total amount of data. The largest fraction of the surface data is from the period before 1928. Aircraft, kite, and registering ${ }^{2}$ or tethered ${ }^{3}$ balloon observations are almost exclusively from the period before 1938. The quantity of the moving platform upper-air data (i.e., data from ships,

\begin{tabular}{|c|c|}
\hline Parameter & Unit \\
\hline Wind speed & $\mathrm{m} \mathrm{s}^{-1}$ \\
\hline Wind direction & $\circ$ \\
\hline$u$ wind & $\mathrm{m} \mathrm{s}^{-1}$ \\
\hline$v$ wind & $\mathrm{m} \mathrm{s}^{-1}$ \\
\hline Surface pressure & $\mathrm{hPa}$ \\
\hline Sea level pressure & $\mathrm{hPa}$ \\
\hline Pressure temperature & ${ }^{\circ} \mathrm{C}$ \\
\hline Temperature & ${ }^{\circ} \mathrm{C}$ \\
\hline Maximum temperature & ${ }^{\circ} \mathrm{C}$ \\
\hline Minimum temperature & ${ }^{\circ} \mathrm{C}$ \\
\hline Grass maximum temperature & ${ }^{\circ} \mathrm{C}$ \\
\hline Grass minimum temperature & ${ }^{\circ} \mathrm{C}$ \\
\hline Soil temperature & ${ }^{\circ} \mathrm{C}$ \\
\hline SST & ${ }^{\circ} \mathrm{C}$ \\
\hline Relative humidity & $\%$ \\
\hline Water vapor pressure & $\mathrm{mm}$ \\
\hline Absolute humidity & $\mathrm{g} \mathrm{m}^{-3}$ \\
\hline Dewpoint temperature & ${ }^{\circ} \mathrm{C}$ \\
\hline Wet-bulb temperature & ${ }^{\circ} \mathrm{C}$ \\
\hline Cloud cover & oktas \\
\hline Sunshine duration & $\mathrm{h}$ \\
\hline Precipitation & $\mathrm{Im}^{-2}$ \\
\hline Precipitation duration & hhmm \\
\hline Evaporation & $\mathrm{I} \mathrm{m}^{-2}$ \\
\hline Actinometric values & ${ }^{\circ} \mathrm{C}$ \\
\hline Irradiation max temperature & ${ }^{\circ} \mathrm{C}$ \\
\hline Irradiation min temperature & ${ }^{\circ} \mathrm{C}$ \\
\hline Sunshine duration percentage & $\%$ \\
\hline Visibility & $\mathrm{m}$ \\
\hline \multicolumn{2}{|l|}{ Present weather } \\
\hline Past weather & \\
\hline
\end{tabular}

aircraft, etc.) is much smaller than that of the regular, station-based upper-air observations. Nevertheless, these data might turn out to be important to improve the quality of future reanalyses, as they often come from oceanic regions that are not covered by any other data source in the historic time. Finally, a few additional, early atmospheric transmission records have been digitized in the framework of ERA-CLIM. Complete lists of all parameters contained in the surface, upper-air, and atmospheric transmission station observations are given in Tables 2-4.

Figure 2 shows the global distribution of the surface stations that have been inventoried. They are partly located in mainland Portugal, on the Portuguese islands of Madeira and the Azores, and in former Portuguese colonies in Africa and Asia. The rest of the stations are located in Chile, covering the full latitudinal transect from $20^{\circ}$ to $55^{\circ} \mathrm{S}$ east of the Pacific Ocean, including Easter Island and the Robinson Crusoe Island in the southeastern $\mathrm{Pa}$ -

${ }^{2}$ Registering balloons are weather balloons carrying registering instruments without being equipped with a radio transmitter.

${ }^{3}$ Tethered balloons are weather balloons kept connected to a line to the ground (tether) during ascent and carrying registering instruments.

TABLE 3. Observed parameters contained in the upper-air station data files. Pressure is only contained in the files based on altitude levels MSL; geopotential height is only in files based on pressure levels.

\begin{tabular}{|l|c|}
\multicolumn{1}{|c|}{ Parameter } & Unit \\
\hline Pressure/geopotential height & $\mathrm{hPa} / \mathrm{gpm}$ \\
\hline Temperature & ${ }^{\circ} \mathrm{C}$ \\
\hline Wind direction & $\circ$ \\
\hline Wind speed & $\mathrm{m} \mathrm{s}^{-1}$ \\
\hline$u$ wind & $\mathrm{m} \mathrm{s}^{-1}$ \\
\hline$v$ wind & $\mathrm{m} \mathrm{s}^{-1}$ \\
\hline Relative humidity & $\%$ \\
\hline Dewpoint difference & $\mathrm{K}^{-1}$ \\
\hline Specific humidity & $\mathrm{g} \mathrm{kg}^{-1}$ \\
\hline
\end{tabular}

TABLE 4. Observed parameters contained in the atmospheric transmission station data files.

\begin{tabular}{|l|c|}
\hline Parameter & Unit \\
\hline Lambda & $\mu \mathrm{m}$ \\
\hline Transmissivity & $\% / 100$ \\
\hline
\end{tabular}


cific and around the South China Sea region (South China, East China, and Philippine Seas, and Sea of Japan). Many of these records start in the nineteenth century: at present, data coverage is for the August 1873-January 1879 and 1894-1941 periods, with efforts now underway to fill the gap in these records for both new versions of 20CR and ERA-CLIM2 (R. Allan 2013, personal communication).

Figure 3 presents the locations of all inventoried upper-air stations, separately for the different observation platforms. The CHUAN stations [most comprehensive historical (i.e., pre-1957), upper-air dataset] that were already available before the ERACLIM project and IGRA stations (most comprehensive radiosonde dataset after 1957) are shown for comparison. The vast majority of all stations and also of the stations shown in the top-left panel of
Fig. 3 are pilot balloon stations, followed by radiosonde stations.

A large number of pilot balloon, registering balloon, and captive balloon stations are located in Europe, India, and Pakistan. Many more such stations can be seen in North and South America, Greenland, Africa, and parts of Asia. Particularly, in parts of South America (e.g., Bolivia), Africa (e.g., Egypt, southeastern Africa), Russia, and Europe (e.g., United Kingdom, France, Spain), the stations are located in areas not at all covered by CHUAN. For other regions, especially Europe and the United States but also India, ERA-CLIM stations are often already available in CHUAN but not for the early periods covered by the ERA-CLIM records (cf. Fig. 4, top).

The ERA-CLIM radiosonde stations are mainly located in the former Soviet Union, France including

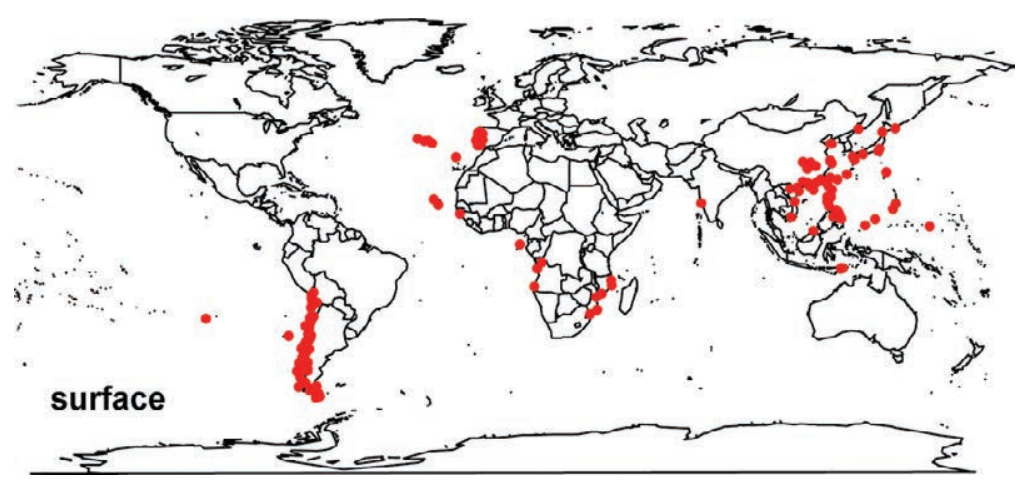

FIG. 2. Map showing the global distribution of all inventoried ERACLIM surface stations.
French overseas territories, the former Portuguese colonies, and some other African countries. For most of them, CHUAN already contains data but again largely for a later time. The additional IGRA stations show the difference to the maximum extent of the post-1957 global radiosonde network. For these stations, there exists presumably no or very little pre-1958 data.

There are many more aircraft stations in the ERA-CLIM data that were not contained in CHUAN

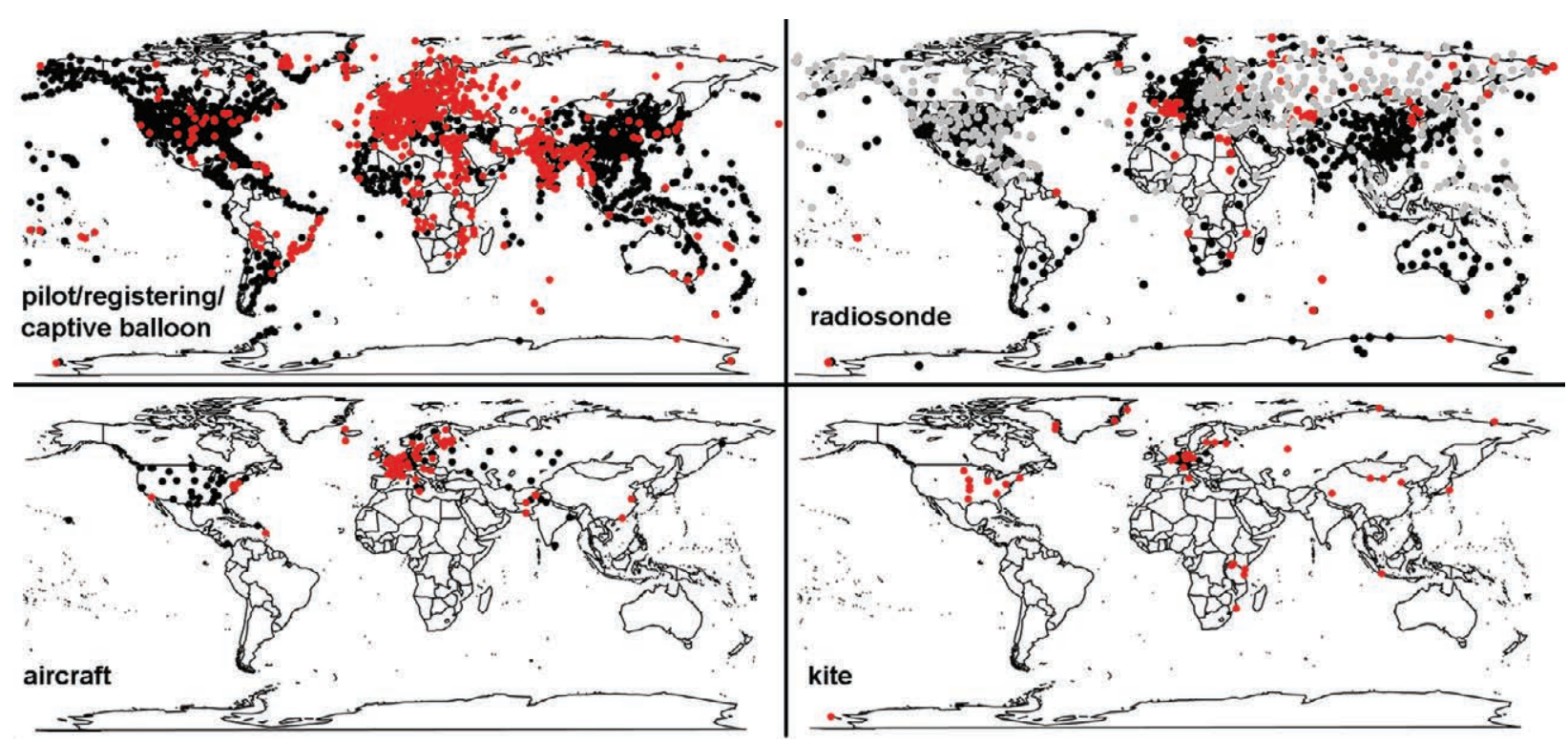

FIG. 3. Maps showing the global distribution of all inventoried ERA-CLIM upper-air stations (red) and additional available CHUAN upper-air stations (black). Measurement platforms are presented separately. (top right) Radiosonde displays all pre-1958 IGRA stations (gray), together with the additional CHUAN and ERA-CLIM stations. 
(e.g., in France, Iceland, Finland, Pakistan, and China). Finally, many additional early kite observations from Europe but also from the United States (for which they are only available as monthly-mean values in CHUAN) have been digitized, and kite stations additional to the ones in CHUAN can be seen for Greenland, Russia, China, Indonesia, and southeastern Africa.

Figure 4 displays the changing upper-air station network in the ERA-CLIM as well as CHUAN datasets with time for the period before 1958. It is clear from both top panels that ERA-CLIM contributes a lot of new stations compared to CHUAN, particularly in the very early periods before the 1940s. For the later periods, there are also many new records, but with a focus on the tropics, the former Soviet Union, and France including overseas territories. Many further records during these periods are filling time gaps that were present in CHUAN. Some records (former Portuguese colonies) continue into the 1970s.

Going back to Fig. 1 in more detail, this graph shows the monthly resolved number of inventoried ERA-CLIM and CHUAN records from 1900 to 1972, when the last upper-air record digitized in ERACLIM ends, subdivided into observation platforms. This representation demonstrates during which periods the new ERA-CLIM observations significantly increase the already available amount of data and that the data rescue efforts in the framework of ERA-CLIM focused on the pre-1958 period. Large amounts of additional pilot balloon records have been inventoried (and partly digitized) for 1920-35, with the new ERA-CLIM data contributing mostly more than $50 \%$ to the available total amount until 1934. The ERA-CLIM pilot balloon records also significantly contribute to the total amount of data during the years 1935-40 and after 1946. The largest contribution of ERA-CLIM to the total radiosonde records occurs during the period 1947-56 and during the early radiosonde era before 1938 (albeit on a very low absolute level in the latter case). The number of kite records is not only strongly increased relative to CHUAN before 1928, but ERA-CLIM also provides the early U.S. kite data as single ascents that were only available as monthly means until now, as mentioned above. With respect to aircraft data (without airship observations that are contained in the moving upperair inventory), the ERA-CLIM dataset has a large relative contribution (often $>50 \%$ ) from 1918 to 1937, with the largest absolute contribution in the 1930s. Also for the registering balloons, the new ERA-CLIM data offer more records than CHUAN most of the time.

The right panels of Figs. 4 and 5 of Stickler et al. (2010) give a good indication of the typical vertical distribution of historical upper-air data over time in the first half of the twentieth century (as can be seen from Fig. 1, the records in these figures, derived for CHUAN but similar to the ERA-CLIM data, are dominated by visually tracked pilot balloons, except for the period before 1918, with radiosondes contributing up to one-third to the total number of records after the mid-1940s): Until the late 1930s, most daytime

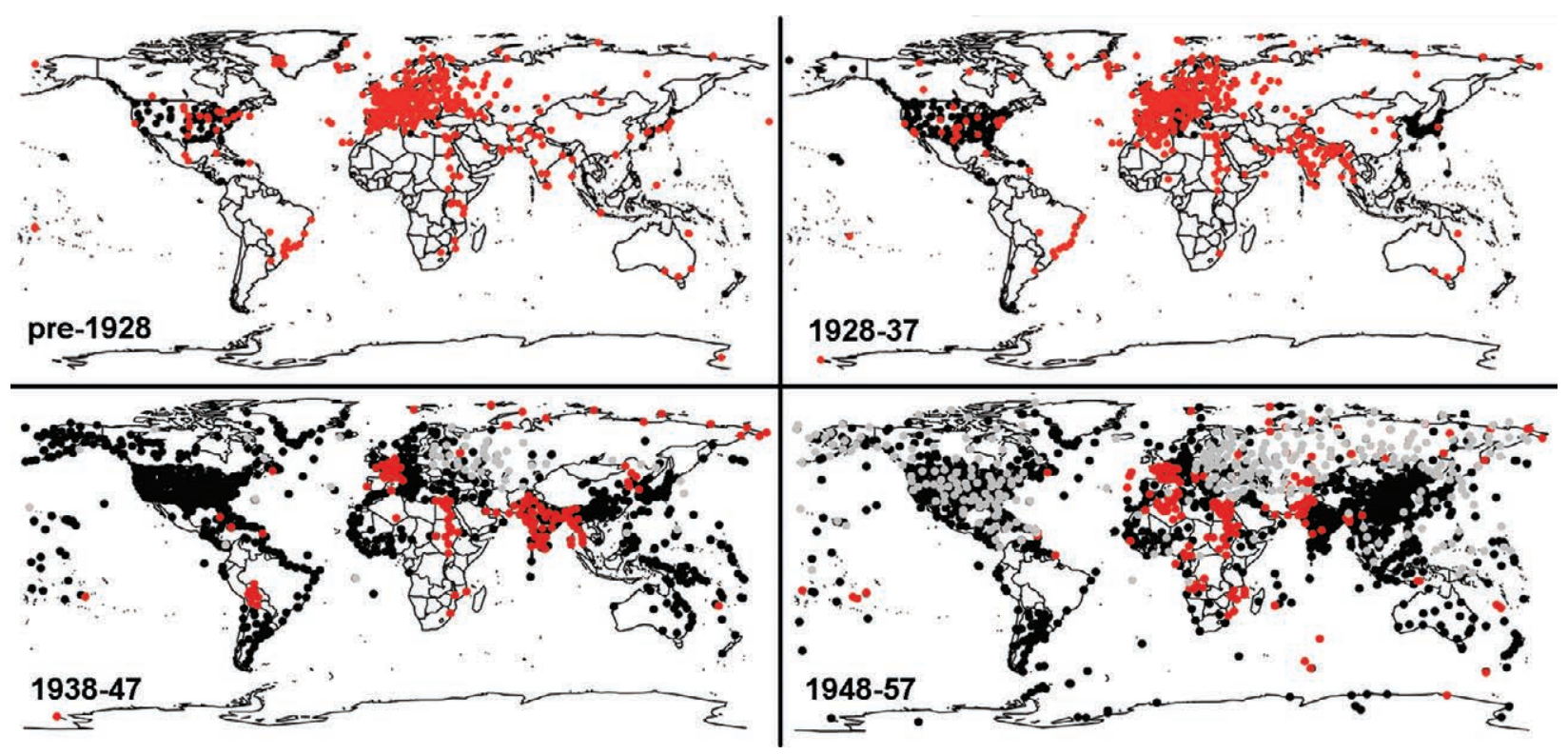

FIG. 4. Maps showing the global distribution of all IGRA radiosonde stations, additional inventoried ERA-CLIM upper-air stations (red), and available CHUAN upper-air stations (black) for the pre-1928 period and for the decades 1928-37, 1938-47, and 1948-57. 


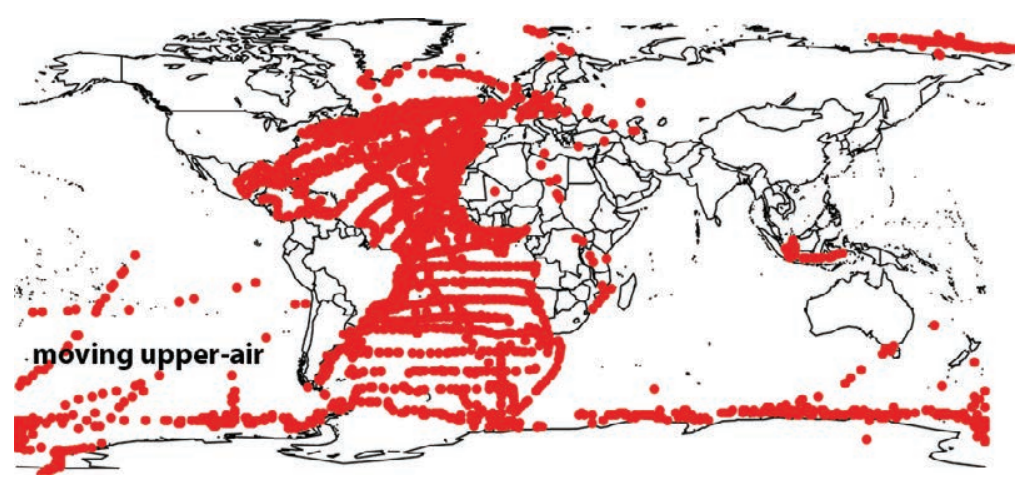

FIG. 5. Map showing the global distribution of the locations of all inventoried ERA-CLIM moving upper-air data.

(0600-1800 UTC) ascents did not reach altitudes higher than 5,000 $\mathrm{m}$ above mean sea level (MSL). In the middle to late 1940 s, already $15 \%-25 \%$ of these ascents reached altitudes of at least 8,000 m MSL. During the same period, the contribution of ascents with top heights of more than $13 \mathrm{~km}$ MSL became significant. From about 1950 on, more than $15 \%$ of the daytime sondes reached altitudes above $20 \mathrm{~km} \mathrm{MSL}$; after 1955, a small part has top levels above $30 \mathrm{~km}$ MSL. For nighttime ascents and climatic regions with high frequencies of cloud cover, the values tend to be lower in case of the visually tracked balloons.

Another estimate of typical heights reached during historical upper-air observations of different types can be obtained from ascents performed during the German Atlantic expedition of 1925-27, spanning a latitudinal range from $53.5^{\circ} \mathrm{N}$ to almost $64^{\circ} \mathrm{S}$, and also digitized in the framework of ERA-CLIM. In these records, the pilot balloon ascents reach altitudes up to 20,500 m MSL, with a median height reached of 4,500 $\mathrm{m}$ MSL. The kite ascents reach maximum heights of 4,870 m MSL, with a median of 2,165 m MSL. Drifting registering balloons reached a maximum height of $14,700 \mathrm{~m}$ MSL, with the median being $6,645 \mathrm{~m}$ MSL.

Figure 5 depicts the global distribution of the location of all inventoried moving upper-air data. The best coverage can be seen in the Atlantic basin. Most of the observations, particularly the regular west-east transects, stem from the German Atlantic expedition of 1925-27 but also from observations made on board of merchant ships and during other scientific cruises. The positions in the top-right corner north of eastern Siberia represent data from the Norwegian north polar expedition of 1918-25, and those in the southeastern Pacific/Southern Ocean and along the Antarctic coastline are from the U.S. military Operation Highjump in 1946-47. Finally, the data points in central Europe correspond to some manned balloon rides going back to 1888 .
EXAMPLES OF USE. Apart from the use for generating data or validating products such as surface-based reanalyses or statistical reconstructions (Brohan et al. 2012), important insights on individual events or for individual stations can often be gained from analyzing the data directly. In the following, we show such an application to several weather extremes by making use of the many pilot balloon wind and radiosonde stations in India and surrounding regions in the ERA-CLIM and CHUAN upper-air datasets.

Two major cyclones and a rainstorm in India (1927-52). De et al. (2005) have listed major cyclones in the northern Indian Ocean in the twentieth century in their Table 7. Figures $6 a$,b show observed winds at different altitudes (depending on data availability) together with 20CR geopotential height (GPH) fields on the closely corresponding pressure levels for two of these major cyclones on days close to the maximum intensity of the storms: 31 October 1927 (Fig. 6a) and 24 October 1949 (Fig. 6b). For 1949, additional radiosonde GPH observations from CHUAN are available. The upper-air analysis of the 1927 storm is only possible with the new ERA-CLIM data. For the storm of 1949, a much more comprehensive analysis is possible with the additional ERA-CLIM data than with the CHUAN and IGRA data alone.

During the cyclone of 29 October-3 November 1927 (Fig. 6a), 300 human lives were lost and 6,000 cattle perished in the coastal region of Nellore, Andhrah Pradesh (De et al. 2005). At $0000 \pm 0300$ UTC 31 October 1927, the center of the low pressure system was located about $400 \mathrm{~km}$ southeast of the coastline of the Indian states of Andhra Pradesh and Orissa, according to 20CR. The reanalysis shows a central $\mathrm{GPH}$ at $800 \mathrm{hPa}$ of less than 1,980 geopotential meters (gpm). The 2,000-m MSL observed ERA-CLIM wind vectors fit relatively well with expected wind directions from the 20CR GPH field in the larger region. Observed wind speeds at this altitude reach magnitudes of $18-20 \mathrm{~m} \mathrm{~s}^{-1}$ in southern India, close to the strong gale-force surface winds in the region of $79 \mathrm{~km} \mathrm{~h}^{-1}\left(\sim 22 \mathrm{~m} \mathrm{~s}^{-1}\right)$ reported in De et al. (2005). $20 \mathrm{CR}$, on the other hand, seems to underestimate the wind speeds at $800 \mathrm{hPa}$ : a rough calculation of the geostrophic wind speed in the region of the two stations with the strongest winds in Fig. 6a from the 20CR GPH field gives only $11.5 \mathrm{~m} \mathrm{~s}^{-1}$, with stronger 
winds of $>20 \mathrm{~m} \mathrm{~s}^{-1}$ modeled only in an annular zone closer to the cyclone center.

During the cyclone of 24 October 1949 (Fig. 6b), 750 lives were lost and 30,000 cattle perished in the region of Machilipatnam, Andhrah Pradesh. According to De et al. (2005), hurricane-force winds of $130 \mathrm{~km} \mathrm{~h}^{-1}\left(\sim 36 \mathrm{~m} \mathrm{~s}^{-1}\right)$ occurred at the surface. The cyclone center in the reanalysis is again located in the
Gulf of Bengal but farther south than in 1927. As for 1927 , observed upper-wind directions agree relatively well with those expected from the 20CR GPH field. However, 20CR suggests even weaker GPH gradients (at $850 \mathrm{hPa}$ in this case) over the Indian subcontinent than in the first case, corresponding to geostrophic wind speeds of clearly less than $20 \mathrm{~m} \mathrm{~s}^{-1}$. In this case, also the upper-air wind observations do not give
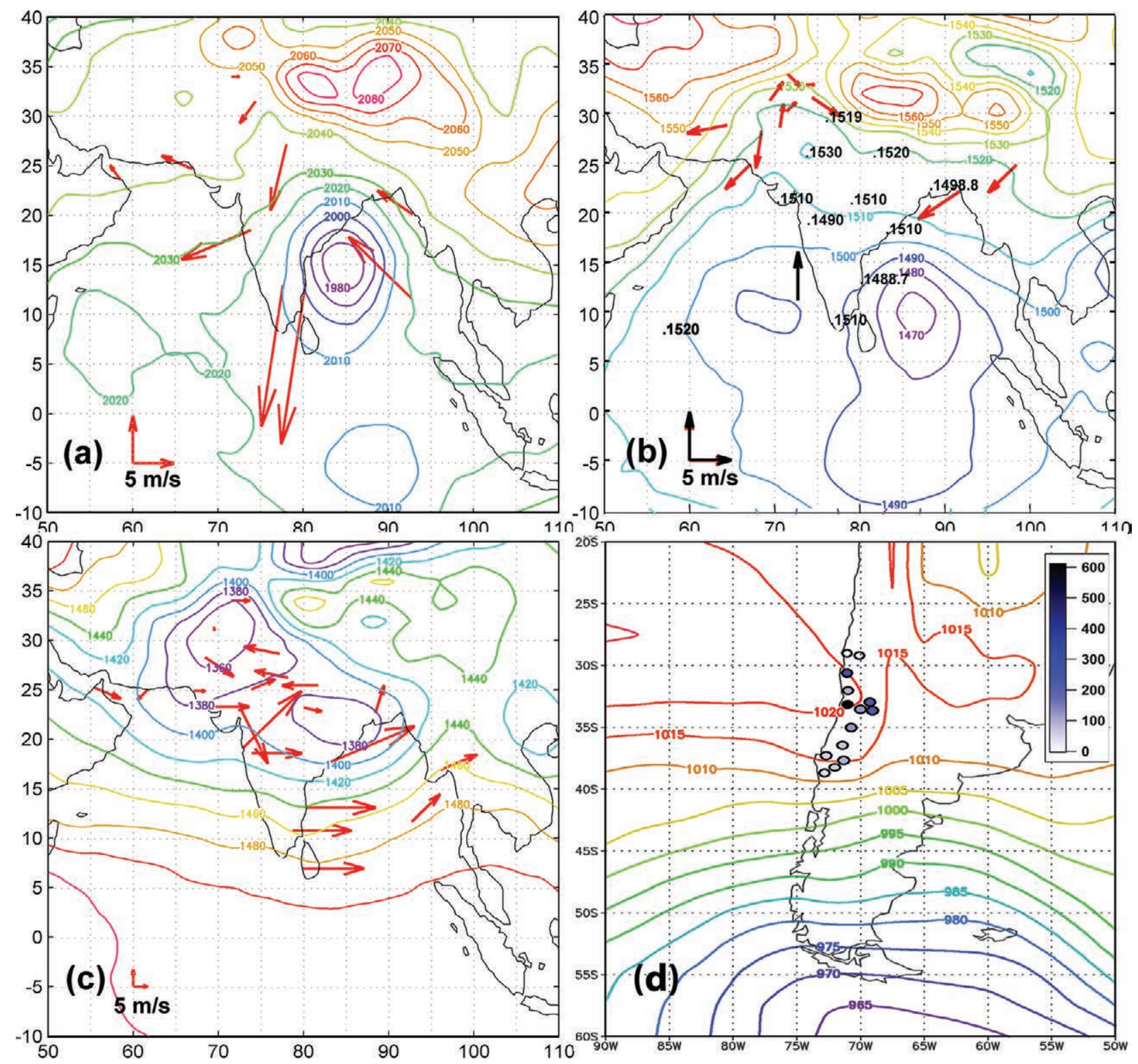

Fig. 6. (a)-(c) ERA-CLIM and CHUAN pilot balloon wind observations (red/black wind vectors) and CHUAN radiosonde GPH observations (black numbers), together with 20CR GPH fields (contour lines), displayed for two major cyclone events in the northern Indian Ocean region (1927 and 1949) and one major rainstorm event affecting the west coast of India in Jul $194 \mathrm{I}$ (according to De et al. 2005): (a) 2,000-m MSL wind and 800-hPa GPH at $0000 \pm 0300$ UTC 3I Oct 1927; (b) I,524-m (I,500-m) MSL ERA-CLIM (CHUAN) wind and 850-hPa GPH at $0000 \pm 0300$ UTC 24 Oct 1949 and observed 850 -hPa CHUAN radiosonde GPH from I500 \pm 0100 UTC 23 Oct 1949; and (c) I,500-m MSL wind and 850-hPa GPH at $0000 \pm 0300$ UTC 2 Jul I94I. (d) ERA-CLIM-observed 3-day precipitation sums (filled circles; $\mathrm{m}^{-2}$ ), together with the NNR sea level pressure field (0000 UTC 20 Aug 1953; contour lines), displayed for a heavy rainfall event between $30^{\circ}$ and $38^{\circ} \mathrm{S}$ in Chile on 19-2I Aug 1953. 
a direct indication of very strong winds: no values above $5 \mathrm{~m} \mathrm{~s}^{-1}$ were observed at 1,500 m MSL in the larger region, although there are admittedly no observations available from the Indian east coast, close to the supposed location of the cyclone. Upper-air GPH observations from radiosondes are available from CHUAN. These display relatively strong differences from the reanalysis for some stations, suggesting that the GPH field in 20CR may not be very well constrained, but do not alone imply very strong geostrophic winds on the east coast either.

Another extreme event in India was a major widespread rain event with maximum intensity on 2 July 1941 that caused severe flooding along large parts of the Indian west coast (Table 6 in De et al. 2005). Figure $6 \mathrm{c}$ depicts the respective ERA-CLIM wind observations at 1,500 $\mathrm{m}$ MSL together with the 20CR 850-hPa GPH field.

20CR shows a deep low (central GPH $<1,360$ gpm), located in northern Pakistan, with a secondary, slightly less intense cyclonic center over northeastern India. This configuration led to an intense westerly flow directed straight toward the western coastal mountain range of India and strong orographic lifting there. By and large, the direction of observed upper-wind vectors and 20CR GPH field agrees again quite well. Even though the GPH gradients in 20CR are relatively strong (note the doubled contour interval compared to Figs. 6a,b), the corresponding geostrophic winds of $\sim 10 \mathrm{~m} \mathrm{~s}^{-1}$ are less intense than the very strong observed upper winds in western India (states of Maharashtra and Gujarat, up to $25 \mathrm{~m} \mathrm{~s}^{-1}$ ). The agreement is better for the even higher observed and modeled wind speeds appearing along the east coast (up to $30 \mathrm{~m} \mathrm{~s}^{-1}$ observed; up to $28 \mathrm{~m} \mathrm{~s}^{-1}$ from 20CR).

A heavy rainfall event in Chile (1953). On 19-21 August 1953, heavy rainfalls occurred in Chile between $30^{\circ}$ and $38^{\circ} \mathrm{S}$. Figure $6 \mathrm{~d}$ displays 3 -day precipitation sums for that period from the newly digitized Chilean ERA-CLIM surface stations together with the sea level pressure field at 0000 UTC 20 August 1953 from NNR. Note that some of the observational parameters digitized in the framework of ERA-CLIM, such as surface precipitation as shown here, and other surface parameters, such as soil temperature, maximum and minimum temperature, evaporation, and humidity in general, are not assimilated into reanalyses at the moment but may be useful for reanalysis validation in the future.

The NNR GPH field displays an intense low south of Cape Horn (central pressure $<965 \mathrm{hPa}$ ) and a welldeveloped southeastern Pacific subtropical high west of northern Chile (central pressure $>1,025 \mathrm{hPa}$ ). This led to a strong pressure gradient between the two systems, connected to a strong westerly flow directed straight toward the Andes Mountains south of $37.5^{\circ} \mathrm{S}$. The relatively strong lee trough east of the central Chilean Andes, leading to a westerly to southwesterly flow in central Chile, possibly contributed to the enhanced transport of moist air into the region affected by the heavy precipitation.

CONCLUSIONS AND OUTLOOK. We have given an overview of the ERA-CLIM historical surface and upper-air data rescue activities in the framework of the EU FP7 project ERA-CLIM. The main purpose of these activities was (and will be in the follow-up project; see below) to provide data for new reanalyses, which will produce continuous, global, three-dimensional estimates of the atmospheric circulation consistent with observations. Various reanalysis experiments have already been or are still being conducted at ECMWF to demonstrate the usefulness of the new data for improving reanalysis quality in certain regions of the world (Dee et al. 2014). Many of the ERA-CLIM surface observations have been assimilated in a new reanalysis of the twentieth century, ERA-20C, which will become available to the public in summer 2014. ERA-20C uses a version of the ECMWF atmospheric model especially prepared for climate applications (Hersbach et al. 2013) and assimilates surface pressure and marine wind observations from ISPD and the International Comprehensive Ocean-Atmosphere Data Set (ICOADS) in addition to those recovered in ERA-CLIM (Poli et al. 2013). The assimilation of these data into ERA-20C and other reanalyses will produce valuable feedback information to the observations community; such information might be used to produce a "corrected" version of the ERA-CLIM and CHUAN datasets. The ERA-CLIM upper-air data provide an independent reference for the validation of other products such as 20CR (e.g., Brönnimann and Stickler 2013). Also, observation errors can be estimated directly from the observations (Wartenburger et al. 2013). Additionally, a homogenization of the upper-air data is being undertaken at the University of Vienna, also a partner in ERA-CLIM, as far as this is possible with the often very short and irregular historical time series.

The data will be made freely available via the project website (www.era-clim.eu), which will also link to the metadatabase containing the complete listing of all inventoried records. The upper-air data (Stickler et al. 2014) are also available online (at http://doi.pangaea .de/I0.I594/PANGAEA.82I222). We have also 
demonstrated the usefulness of the newly available data for analyzing extreme weather events in the pre-1958 period. Ultimately these data will help improve our ability to produce extended climate reanalyses based on the entire instrumental record (Dee et al. 2014).

The digitized surface pressure and temperature data have been submitted to the ISPD and the International Surface Temperature Initiative. To the extent possible, the digitized upper-air data will be homogenized by the University of Vienna project partners. New ERA-CLIM productions at ECMWF, including ERA-20C, will make use of the data. The digitization of the cataloged, historical data will continue in the framework of ERA-CLIM2, the follow-up project to ERA-CLIM, which started in January 2014.

ACKNOWLEDGMENTS. All authors received funding from the EU FP7 project ERA-CLIM (Grant 265229). RA is also supported with funds from the EU FP7 European Reanalysis and Observations for Monitoring (EURO4M) project and the Met Office Hadley Centre Climate Program (HCCP). The 20CR and NNR data have been downloaded from the NOAA ESRL website. Upper-air data recovered by FFCUL were kindly provided by the Instituto Português do Mar e da Atmosfera through their Anuários Climatológicos de Portugal (IV Parte-Territórios UltramarinosObservações de Altitude).

\section{REFERENCES}

Allan, R., P. Brohan, G. P. Compo, R. Stone, J. Luterbacher, and S. Brönnimann, 2011: The International Atmospheric Circulation Reconstructions over the Earth (ACRE) initiative. Bull. Amer. Meteor. Soc., 92, 1421-1425, doi:10.1175/2011BAMS3218.1.

Berson, A., 1910: Bericht über die aerologische Expedition des Königlichen Aeronautischen Observatoriums nach Ostafrika im Jahre 1908. Vieweg, 119 pp.

Brohan, P., R. Allan, E. Freeman, D. Wheeler, C. Wilkinson, and F. Williamson, 2012: Constraining the temperature history of the past millennium using early instrumental observations. Climate Past, 8, 1551-1563, doi:10.5194/cp-8-1551-2012.

Brönnimann, S., and A. Stickler, 2013: Aerological observations in the tropics in the early twentieth century. Meteor. Z., 22, 349-358, doi:10.1127/0941 $-2948 / 2013 / 0458$.

Compo, G. P., and Coauthors, 2011: The Twentieth Century Reanalysis project. Quart. J. Roy. Meteor. Soc., 137, 1-28, doi:10.1002/qj.776.

De, U. S., R. K. Dube, and G. S. Prakasa Rao, 2005: Extreme weather events over India in the last 100 years. J. Indian, Geophys. Union, 9, 173-187.
Dee, D. P., M. Balmaseda, G. Balsamo, R. Engelen, A. J. Simmons, and J.-N. Thépaut, 2014: Toward a consistent reanalysis of the climate system. Bull. Amer. Meteor. Soc., in press, doi:10.1175/BAMS -D-13-00043.1.

de Quervain, A., P.-L. Mercanton, and A. Stolberg, 1920: Ergebnisse der Schweizerischen Grönlandexpedition 1912-1913. Kommission für Veröffentlichungen der Schweizerischen Naturforschenden Gesellschaft, $402 \mathrm{pp}$.

Durre, I., R. S. Vose, and D. B. Wuertz, 2006: Overview of the Integrated Global Radiosonde Archive. J. Climate, 19, 53-68, doi:10.1175/JCLI3594.1.

Ebita, A., and Coauthors, 2011: The Japanese 55-year Reanalysis "JRA-55": An interim report. SOLA, 7, 149-152, doi:10.2151/sola.2011-038.

Grimminger, G., and W. C. Haines, 1939: Meteorological Results of the Byrd Antarctic Expeditions 1928-30, 1933-35; Tables. Monthly Weather Review Supplement, Vol. 41, U.S. Weather Bureau, 377 pp.

Hersbach, H., C. Peubey, A. Simmons, P. Poli, and D. Dee, 2013: ERA-20CM: A twentieth century atmospheric model ensemble. ECMWF ERA Rep. $16,44 \mathrm{pp}$.

Hobbs, W. H., and S. P. Fergusson, 1931: Reports of the Greenland Expeditions of the University of Michigan. Part I: Aërology, Expeditions of 1926 and 1927-29. University of Michigan Press, 259 pp.

Holzapfel, R., W. Kopp, and K. Wegener, 1939: Meteorologie, die Ergebnisse. Wissenschaftliche Ergebnisse der deutschen Grönland-Expedition Alfred Wegener 1929 und 1930/1931, Vol. 4, K. Wegener, Ed., Brockhaus, 32-469.

Kistler, R., and Coauthors, 2001: The NCEP-NCAR 50-Year Reanalysis: Monthly means CD-ROM and documentation. Bull. Amer. Meteor. Soc., 82, 247-268, doi:10.1175/1520-0477(2001)0822.3.CO;2.

Kuhlbrodt, E., and J. Reger, 1933: Die aerologischen Methoden und das Aerologische Beobachtungsmaterial. Deutsche Atlantische Expedition auf dem Forschungsschiff „Meteor", Wissenschaftliche Ergebnisse, Vol. 15, A. Defant, Ed., de Gruyter, 1-305.

Meteorological Services of Canada, 1940: Canadian Polar Year Expeditions 1932-33: Meterorology: Cape Hope's Advance Coppermine Chesterfield Inlet Meanook, Vol. 1, Patenaude, $452 \mathrm{pp}$.

Morozova, A. L., and M. A. Valente, 2012: Homogenization of Portuguese long-term temperature data series: Lisbon, Coimbra and Porto. Earth Syst. Sci. Data, 4, 187-213, doi:10.5194/essd-4-187-2012.

Poli, P., and Coauthors, 2013: The data assimilation system and initial performance evaluation of the ECMWF pilot reanalysis of the 20th-century 
assimilating surface observations only (ERA-20C). ECMWF ERA Rep. 14, 59 pp.

Ramella-Pralungo, L., L. Haimberger, A. Stickler, and S. Brönnimann, 2014: A global radiosonde and tracked balloon archive on 16 pressure levels (GRASP) back to 1905-Part 1: Merging and interpolation to 00:00 and 12:00 GMT. Earth Syst. Sci. Data, 6, 185-200, doi:10.5194/essd-6-185-200-2014.

Saha, S., and Coauthors, 2010: The NCEP Climate Forecast System Reanalysis. Bull. Amer. Meteor. Soc., 91, 1015-1057, doi:10.1175/2010BAMS3001.1.

Stickler, A., and Coauthors, 2010: The Comprehensive Historical Upper Air Network. Bull. Amer. Meteor. Soc., 91, 741-751, doi:10.1175/2009BAMS2852.1.

— CLIM historical upper-air data. Earth Syst. Sci. Data, 6, 29-48, doi:10.5194/essd-6-29-2014.

Süring, R., 2013: Report by A. Berson about the aerological expedition of the Royal Aeronautic Observatory to East Africa in 1908. Meteor. Z., 22, 343-348, doi:10.1127/0941-2948/2013/0494.
Sverdrup, H. U., 1933a: The Norwegian north polar expedition with the "Maud" 1918-1925: Scientific results: Vol. 2, meteorology: Part I: Discussion. Geofysisk Institutt Bergen Rep., 331 pp.

- 1933 b: The Norwegian north polar expedition with the "Maud" 1918-1925: Scientific results: Vol. 3: Meteorology: Part II: Tables. Geofysisk Institutt Bergen Rep., 577 pp.

Thorne, P. W., and Coauthors, 2011: Guiding the creation of a comprehensive surface temperature resource for twenty-first-century climate science. Bull. Amer. Meteor. Soc., 92, ES40-ES47, doi:10.1175/2011BAMS3124.1.

Uppala, S. M., and Coauthors, 2005: The ERA-40 ReAnalysis. Quart. J. Roy. Meteor. Soc., 131, 2961-3012, doi:10.1256/qj.04.176.

Wartenburger, R., S. Brönnimann, and A. Stickler, 2013: Observation errors in early historical upperair observations. J. Geophys. Res. Atmos., 118, 12 012-12 028, doi:10.1002/2013JD020156. 